\title{
Sepsis Stimulates Nonlysosomal, Energy-dependent Proteolysis and Increases Ubiquitin mRNA Levels in Rat Skeletal Muscle
}

\author{
Greg Tiao, Julie M. Fagan, ${ }^{\star}$ Neil Samuels, ${ }^{\star}$ J. Howard James, Karen Hudson, ${ }^{\star}$ Michael Lieberman, ${ }^{\ddagger}$ Josef E. Fischer, and \\ Per-Olof Hasselgren \\ Departments of Surgery and ${ }^{\ddagger}$ Molecular Genetics and Biochemistry, University of Cincinnati, Cincinnati, Ohio 45267; ${ }^{\S}$ Shriners Burns \\ Institute, Cincinnati, Ohio, 45219; and *Department of Animal Sciences, Rutgers University, New Brunswick, New Jersey 08903
}

\begin{abstract}
We tested the role of different intracellular proteolytic pathways in sepsis-induced muscle proteolysis. Sepsis was induced in rats by cecal ligation and puncture; controls were sham operated. Total and myofibrillar proteolysis was determined in incubated extensor digitorum longus muscles as release of tyrosine and 3-methylhistidine, respectively. Lysosomal proteolysis was assessed by using the lysosomotropic agents $\mathrm{NH}_{4} \mathrm{Cl}$, chloroquine, leupeptin, and methylamine. $\mathrm{Ca}^{2+}$-dependent proteolysis was determined in the absence or presence of $\mathrm{Ca}^{2+}$ or by blocking the $\mathrm{Ca}^{2+}$-dependent proteases calpain I and II. Energy-dependent proteolysis was determined in muscles depleted of ATP by 2-deoxyglucose and 2.4-dinitrophenol. Muscle ubiquitin $\mathrm{mRNA}$ and the concentrations of free and conjugated ubiquitin were determined by Northern and Western blots, respectively, to assess the role of the ATP-ubiquitin-dependent proteolytic pathway. Total and myofibrillar protein breakdown was increased during sepsis by 50 and $440 \%$, respectively. Lysosomal and $\mathrm{Ca}^{2+}$-dependent proteolysis was similar in control and septic rats. In contrast, energy-dependent total and myofibrillar protein breakdown was increased by $172 \%$ and more than fourfold, respectively, in septic muscle. Ubiquitin mRNA was increased severalfold in septic muscle. The results suggest that the increase in muscle proteolysis during sepsis is due to an increase in nonlysosomal energy-dependent protein breakdown, which may involve the ubiquitin system. (J. Clin. Invest. 1994. 94:2255-2264.) Key words: sepsis - muscle $\cdot$ lysosomal proteolysis $\cdot \mathrm{Ca}^{2+}$-dependent proteolysis $\cdot$ energy-dependent proteolysis $\bullet$ ubiquitin
\end{abstract}

\section{Introduction}

Muscle catabolism during sepsis is caused primarily by in creased protein breakdown, in particular myofibrillar protein breakdown (1), although reduced protein synthesis (2) and inhibited muscle amino acid uptake (3) may contribute to the catabolic response. It has been established that glucocorticoids (4) and certain cytokines, in particular tumor necrosis factor

Address correspondence to Per-Olof Hasselgren, M.D., Department of Surgery, University of Cincinnati, 231 Bethesda Avenue, ML \#558, Cincinnati, OH 45267.

Received for publication 2 February 1994 and in revised form 2 August 1994.

J. Clin. Invest.

(C) The American Society for Clinical Investigation, Inc. $0021-9738 / 94 / 12 / 2255 / 10 \quad \$ 2.00$

Volume 94, December 1994, 2255-2264 and interleukin 1 (5-7), are important mediators of muscle proteolysis during sepsis. However, the intracellular mechanisms responsible for the increase in muscle protein breakdown during sepsis have not been defined.

Several proteolytic pathways are involved in the intracellular degradation of proteins. The proteolytic mechanism that has probably been studied most extensively is the lysosomal pathway, generally considered to be responsible for increased overall protein breakdown in various pathophysiological conditions (8). The lysosomal proteolytic pathway is stimulated by lack of insulin and amino acids in skeletal and cardiac muscle (912). Muscle contains several well-characterized lysosomal proteases, including the cysteine proteases cathepsin $\mathrm{B}, \mathrm{H}$, and $\mathrm{L}$, and the aspartic protease cathepsin D (13). The role of lysosomal protein degradation can be investigated by using substances that block lysosomal acidification, e.g., $\mathrm{NH}_{4} \mathrm{Cl}$, chloroquine, or methylamine, or compounds that inhibit lysosomal proteases, e.g., leupeptin (14).

In addition to the lysosomal proteolytic pathway, there is evidence for at least four non-lysosomal mechanisms of protein degradation in skeletal muscle. A proteolytic pathway that requires ATP and degrades ubiquitin-conjugated proteins was initially thought to catalyze the breakdown of abnormal and shortlived regulatory proteins (15). However, recent studies provided evidence that this ATP-ubiquitin-dependent proteolytic pathway also plays an important role in muscle protein degradation induced by starvation, denervation, metabolic acidosis, and cancer (16-20). In contrast, the role of energy-ubiquitin-dependent muscle proteolysis during sepsis is not known. Ubiquitin is a small 76-amino acid molecule that is highly conserved across mammalian evolution with little variation in its amino acid sequence from yeast to man (15). ATP is required both for ligation of the carboxy terminal of ubiquitin to amino groups of proteins and for the degradation of the ubiquitin-protein conjugates (15). In addition to the ubiquitin-dependent pathway, muscle also contains a nonlysosomal ATP-dependent protease that degrades proteins that are not conjugated to ubiquitin (21), but the role of this enzyme in hydrolyzing intracellular proteins is not known. In previous studies, the role of energydependent proteolytic pathways was tested by depleting incubated muscles of ATP with 2-deoxyglucose (2-DG) ${ }^{1}$ and 2,4dinitrophenol (DNP) $(16,19,21,22)$.

Another nonlysosomal proteolytic pathway involves the $\mathrm{Ca}^{2+}$-dependent cysteine proteases calpain I and II $(23,24)$. The role of these enzymes in vivo remains unclear but they

1. Abbreviations used in this paper: CLP, cecal ligation and puncture; 2-DG, deoxyglucose; DNP, 2,4-dinitrophenol; E-64, trans-epoxysuccinyl-L-leucylamido (4-guanidino) butane; EDL, extensor digitorum longus; LSB, low salt buffer; 3-MH, 3-methylhistidine; PRB, pyrophosphate relaxing buffer; PVDF, polyvinylidenedifluoride. 
have been implicated in the pathogenesis of muscle breakdown after denervation (25) and in muscle dystrophy (26). The breakdown of proteins by the calpains does not require energy and is actually stimulated in vitro by energy depletion (22). The compound trans-epoxysuccinyl-L-leucylamido (4-guanidino) butane (E-64) blocks the calpains and can therefore be used to test the role of $\mathrm{Ca}^{2+}$-dependent proteolysis. Finally, evidence was found recently for an energy-independent nonlysosomal proteolytic pathway that may play a role in removing abnormal proteins and proteins damaged by reactive oxygen species $(27,28)$.

The purpose of the present study was to assess the role of different intracellular proteolytic pathways in the increased muscle proteolysis observed during sepsis. This was done by determining the effects of different proteolytic inhibitors on protein breakdown in muscles from sham-operated control rats and from rats made septic by cecal ligation and puncture (CLP). This approach to assess the activity of the different proteolytic pathways by using multiple inhibitors has been developed primarily by Goldberg and collaborators $(9,16-19)$. In addition, muscle levels of ubiquitin mRNA and of free and conjugated ubiquitin were determined to assess more specifically the influence of sepsis on the ATP-ubiquitin-dependent proteolytic pathway.

\section{Methods}

Sepsis was induced in male Sprague-Dawley rats (40-60 g) by CLP as described previously (1-4). Sham-operated control rats underwent laparotomy and manipulation, but no ligation or puncture, of the cecum. Both septic and sham-operated rats were resuscitated with saline (10 $\mathrm{ml} / 100 \mathrm{~g}$ body $\mathrm{wt}$ ) administered subcutaneously on the back at the time of surgery and were fasted but had free access to water after the surgical procedures. CLP is a clinically relevant model, resembling sepsis in patients caused by intraabdominal abscess and devitalized tissue. Mortality rates and hemodynamic and metabolic changes induced by CLP in rats were described in previous reports from our (29) and other laboratories (30). It should be noted that CLP in rats is more indicative of an acute septic insult than a chronic septic process because the majority of animals die after 24-48 h. In the present report, metabolic studies were performed $16 \mathrm{~h}$ after CLP or sham operation. In previous reports, rats exhibited signs of hypermetabolic hyperdynamic sepsis at this time point whereas, at later time points, rats became hypodynamic and developed evidence of septic shock $(29,30)$.

Muscle incubations. $16 \mathrm{~h}$ after CLP or sham operation, rats were anesthetized with pentobarbital ( $45 \mathrm{mg} / \mathrm{kg}$ i.p.) and both extensor digitorum longus (EDL) muscles were gently dissected and excised with intact tendons. The muscles were mounted on stainless steel supports at approximate resting length and immediately transferred to $3 \mathrm{ml}$ of oxygenated $\left(\mathrm{O}_{2} / \mathrm{CO}_{2}=95: 5\right) \mathrm{Krebs}-$ Henseleit bicarbonate buffer $(\mathrm{pH}$ 7.4) with $5 \mathrm{mM}$ glucose unless stated otherwise. The time point for metabolic studies was chosen on the basis of previous reports in which total and myofibrillar muscle protein breakdown rates, measured as release of tyrosine and 3-methylhistidine (3-MH), respectively, were substantially increased and protein synthesis rates were reduced in EDL muscles $(1,4,6,31)$. Muscles were incubated fixed at resting length rather than flaccid because previous studies from our $(31,32)$ and other laboratories (33) demonstrated that protein balance and energy levels are better maintained in muscles incubated at resting length than in muscles allowed to shorten during incubation.

Protein synthesis. Muscle protein synthesis rates were measured to test whether increased protein breakdown rates were a reflection of increased protein turnover (with increased rates of both protein synthesis and breakdown). For the measurement of protein synthesis rates, muscles were preincubated in a shaking water bath at $37^{\circ} \mathrm{C}$ for $60 \mathrm{~min}$ in
$3 \mathrm{ml}$ of medium of the same composition as described above. After preincubation, the muscles were transferred to $3 \mathrm{ml}$ of fresh medium with the addition of $\left[{ }^{14} \mathrm{C}\right]$ phenylalanine $(0.05 \mu \mathrm{Ci} / \mathrm{ml} ; 0.5 \mathrm{mM})$. After incubation for $2 \mathrm{~h}$, the amount of phenylalanine incorporated into trichloroacetic acid precipitated protein was determined as described previously $(2,31)$. Protein synthesis rates are reported as nmol phenylalanine/g wet wt per $2 \mathrm{~h}$.

Total and myofibrillar protein breakdown. For determination of protein breakdown rates, bilateral muscles were individually preincubated for $60 \mathrm{~min}$ (except in the experiments in which muscles were energy depleted when preincubation was carried out for $90 \mathrm{~min}$; see below) at $37^{\circ} \mathrm{C}$ in a shaking water bath. After preincubation, one muscle was homogenized in $0.4 \mathrm{M}$ perchloric acid for determination of tissue free tyrosine and $3-\mathrm{MH}$ as described previously $(1,32)$. The contralateral muscle was transferred to $3 \mathrm{ml}$ of fresh medium of the same composition as described above with the addition of $0.5 \mathrm{mM}$ cycloheximide to prevent reincorporation of amino acids released during proteolysis. Muscles were incubated for $2 \mathrm{~h}$ at $37^{\circ} \mathrm{C}$ during which time the incubation flasks were repeatedly gassed with $\mathrm{O}_{2} / \mathrm{CO}_{2}$ (95:5). After incubation, the medium was sampled for determination of tyrosine and 3-MH and muscles were homogenized in $0.4 \mathrm{M}$ perchloric acid for determination of tissue free tyrosine and 3-MH by HPLC, as described in detail previously (1, 32 ). Total and myofibrillar (actin and myosin) protein breakdown rates were determined from the release into the incubation medium of tyrosine and 3-MH, respectively, corrected for changes in tissue levels of the amino acids during incubation. 3-MH is present in both actin and myosin in white, fast-twitch skeletal muscle (34). Therefore, release of 3-MH from incubated EDL muscles reflects actin and/or myosin breakdown. In recent studies, we observed that the release of tyrosine and 3-MH from incubated rat muscles was constant during incubation for $2 \mathrm{~h}$ and that tissue levels of free tyrosine increased slightly and those of 3MH decreased during incubation (32). Thus, it is important to monitor changes in tissue levels of the amino acids during incubation when protein breakdown rates are calculated in this in vitro system. Net production of free tyrosine was calculated as amount of tyrosine released into the medium plus the increase in tissue free tyrosine observed during incubation; net production of 3-MH was calculated as amount of 3-MH released into the medium minus the decrease in tissue free 3-MH observed during incubation. Total and myofibrillar protein breakdown rates are reported as nmol tyrosine/g wet wt per $2 \mathrm{~h}$ and $\mathrm{nmol} 3-\mathrm{MH} / \mathrm{g}$ wet wt per $2 \mathrm{~h}$, respectively.

To test the role of lysosomal proteolysis, muscles were incubated in medium as described above or in medium with addition of either $10 \mathrm{mM} \mathrm{NH}_{4} \mathrm{Cl}, 250 \mu \mathrm{M}$ chloroquine, $30 \mu \mathrm{M}$ leupeptin, or $10 \mathrm{mM}$ methylamine. $\mathrm{NH}_{4} \mathrm{Cl}$, chloroquine, and methylamine inhibit proteolysis by raising intralysosomal $\mathrm{pH}$, whereas leupeptin inhibits lysosomal cysteine proteases (14). Different substances were used since none of the substances is completely specific in its inhibition of lysosomal protein breakdown; for example, leupeptin inhibits the nonlysosomal cysteine and serine proteases in addition to blocking these classes of enzymes in the lysosome.

The role of $\mathrm{Ca}^{2+}$-dependent proteolysis was tested by incubating muscles in medium from which $\mathrm{Ca}^{2+}$ had been omitted or in regular Krebs-Henseleit bicarbonate buffer in which $\mathrm{Ca}^{2+}$ is present at $2.5 \mathrm{mM}$ and by incubating muscles in the absence or presence of $100 \mu \mathrm{M} \mathrm{E}-64$ which blocks calpain I and II (35). It should be noted that E-64 is not completely specific for calpain I and II since it also blocks the lysosomal cysteine proteases cathepsin $\mathrm{B}, \mathrm{H}$, and $\mathrm{L}$ (35). In these experiments, all muscles were incubated in the presence of $10 \mathrm{mM}$ methylamine to inhibit basal lysosomal protein breakdown so that any difference between muscles incubated with or without E-64 reflected $\mathrm{Ca}^{2+}$-dependent proteolysis. In all experiments described above, the different substances were present in the medium both during the 60 -min preincubation and the 2-h incubation period.

To study the role of energy-dependent proteolysis, muscles were depleted of intracellular ATP by 90 -min preincubation in medium containing $5 \mathrm{mM}$ 2-DG and $0.2 \mathrm{mM}$ DNP (22). Glucose was omitted from the incubation medium to which 2-DG and DNP were added. ATP- 
depleted muscles were then incubated for $2 \mathrm{~h}$ in the presence of $5 \mathrm{mM}$ 2-DG and $0.2 \mathrm{mM}$ DNP and compared with muscles preincubated and incubated in the presence of $5 \mathrm{mM}$ glucose. All muscles were incubated in $\mathrm{Ca}^{2+}$-free medium (22) containing $10 \mathrm{mM}$ methylamine, $1 \mathrm{mU} / \mathrm{ml}$ insulin, and the branched-chain amino acids leucine, isoleucine, and valine present at concentrations five times those found in rat plasma (36). Methylamine, insulin, and the branched-chain amino acids were added to the incubation medium to block lysosomal protein breakdown. Therefore, in these experiments, changes induced by incubating muscles in the presence of 2-DG and DNP reflect nonlysosomal, $\mathrm{Ca}^{2+}$-independent, energy-dependent proteolysis. Total and myofibrillar protein breakdown rates were determined as described above.

ATP levels were determined in muscles after the 2-h incubation period. Muscles were removed from the incubation medium and immediately frozen in liquid $\mathrm{N}_{2}$ and stored at $-70^{\circ} \mathrm{C}$ until analysis. ATP was measured in neutralized muscle extracts as described previously (22) by a chemiluminescence assay (37) using firefly luciferase (Analytical Luminescence Laboratory, San Diego, CA). In previous studies, tissue levels of ATP were almost completely abolished when muscles were incubated with 2-DG and DNP as described here (22). In the same studies, muscles generated ATP and metabolized glucose after recovery in medium without inhibitors of energy metabolism, suggesting that the ATP-depleted muscles were not irreversibly damaged but were still viable.

Fractionation of sarcoplasmic and myofibrillar proteins. Sarcoplasmic and myofibrillar protein fractions were prepared from EDL muscles of sham-operated and septic rats as described previously (38). The tissue was homogenized in $5 \mathrm{vol}$ of pyrophosphate relaxing buffer (PRB) consisting of the following (mM): $2 \mathrm{Na}_{4} \mathrm{P}_{2} \mathrm{O}_{7}, 10$ Tris maleate (pH 6.8), $10 \mathrm{KCl}, 2 \mathrm{MgCl}_{2}, 2$ EGTA, and 1 dithiothreitol. The homogenate was centrifuged at $800 \mathrm{~g}$ for $10 \mathrm{~min}$ at $4^{\circ} \mathrm{C}$. The supernatant was centrifuged at $100,000 \mathrm{~g}$ for $2 \mathrm{~h}$ at $4^{\circ} \mathrm{C}$. The resulting supernatant constituted the sarcoplasmic proteins. The $800 \mathrm{~g}$ pellet was washed four times in 10 vol of low salt buffer (LSB) ( $\mathrm{pH} 6.8)$ containing the same components as PRB but without $2 \mathrm{mM} \mathrm{Na}_{4} \mathrm{P}_{2} \mathrm{O}_{7}$. The pellet was then washed once in LSB with $0.02 \%$ Triton $\mathrm{X}-100$, once in LSB with $0.02 \% \mathrm{Na}$-deoxycholate, and twice in LSB. The resulting pellet, which constituted the myofibrillar proteins, was solubilized in $5 \mathrm{vol}$ of PRB. The amount of protein in the sarcoplasmic and myofibrillar fractions was determined according to Lowry et al. (39) using bovine serum albumin (BSA) as standard.

Ubiquitin mRNA levels. Ubiquitin mRNA levels were determined in EDL muscles by Northern blot analysis $16 \mathrm{~h}$ after sham operation or CLP. RNA was extracted from muscles pooled from five rats according to standard protocols (40).

Initially, a rat ubiquitin cDNA probe was generated by polymerase chain reaction (PCR). Because the rat ubiquitin gene sequence has not been reported, the human ubiquitin gene sequence was used to construct primers for the PCR. Two 20-bp primers were synthesized (University of Cincinnati DNA Core Facility) based on the human ubiquitin sequence, nucleic acids 30-49 (TAAGACCATCACCCTCGAGG) on the sense strand and 185-164 (TGGATGTTGTAGTCAGACAGGG) on the antisense strand. cDNA was generated from rat muscle RNA by reverse transcription. PCR was performed under standard conditions. The PCR product obtained after 40 cycles was fractionated on a $4 \%$ agarose gel and found to be $156 \mathrm{bp}$. Because the primers used for the PCR reaction only encompassed a portion of the full-length human ubiquitin cDNA (from nucleic acid 30 to 185 ), the $156 \mathrm{bp} \mathrm{PCR} \mathrm{product}$ encoded for only a portion of a full-length rat ubiquitin cDNA.

The PCR product was cloned using the TA cloning kit (Invitrogen, San Diego, CA). A plasmid containing the ubiquitin insert was sequenced (U. S. Biochemical Corp., Cleveland, $\mathrm{OH}$ ) and the first 128 bp were obtained. This sequence was $96 \%$ (123/128) homologous to a group of ubiquitin sequences including the human, bovine, chicken, and mouse genes (National Center for Biotechnology Information, Washington, DC). When this sequence was translated into the corresponding amino acids, a 97\% (41/42) match to a series of reported ubiquitin proteins was obtained. The single amino acid mismatch was a glycine for valine substitution. The codons for valine and glycine differ only at their second position, with valine encoded by GUN and glycine encoded by GGN ( $\mathrm{N}$ may be any nucleotide). This difference may reflect a sequencing error as the sequenase enzyme has a $1 \%$ rate of inaccurate replication. These results confirmed that the generated probe was to ubiquitin.

This probe was used for Northern blot analysis. Muscle RNA ( 10 $\mu \mathrm{g}$ ) was denatured in glyoxal and fractionated on $1 \%$ agarose gel in 10 $\mathrm{mM}$ sodium phosphate, $\mathrm{pH}$ 7.0. The RNA was transferred to nylon membranes (Micron Separation, Inc., Westborough, MA) by capillary action in $25 \mathrm{mM}$ sodium phosphate (pH 6.4) overnight. RNA was covalently attached to the nylon membrane by ultraviolet light. The blot was prehybridized for $4 \mathrm{~h}$ in $50 \%$ formamide, $5 \times$ sodium chloridesodium citrate solution (SSC) $(1 \times \mathrm{SSC}=0.15 \mathrm{M} \mathrm{NaCl}, 15 \mathrm{mM} \mathrm{Na}-$ citrate, $\mathrm{pH} 7.0$ ), $50 \mathrm{mM}$ sodium phosphate, $\mathrm{pH} 7.0,1 \mathrm{mM}$ EDTA, $2 \%$ sodium dodecyl sulfate (SDS), 10× Denhardt's solution, and $10 \mu \mathrm{g} /$ $\mathrm{ml}$ salmon sperm at $42^{\circ} \mathrm{C}$. The probe was labeled by random priming with $\left[\alpha^{32} \mathrm{P}\right]$ ATP (Stratagene, LaJolla, CA). The blots were hybridized with $1 \times 10^{8} \mathrm{cpm}$ of labeled probe overnight at $42^{\circ} \mathrm{C}$ in the same buffer that was used for prehybridization except the sodium phosphate concentration was decreased to $20 \mathrm{mM}$ and Denhardt's solution to normal concentration. The blots were washed twice in $1 \times$ SSC, $0.1 \%$ SDS at room temperature and autoradiographed for $24 \mathrm{~h}$ at $-70^{\circ} \mathrm{C}$. An 18$S$ rat ribosomal oligonucleotide probe (GACAAGCATATGCTACTGGC) was used to control for equal loading of RNA. Autoradiographs were quantitated on a Phosphorimager using the Image Quant Program (Molecular Dynamics Inc., Sunnyvale, CA).

Determination of free and conjugated ubiquitin. Free and conjugated ubiquitin levels were determined in EDL muscles by Western blot analysis $16 \mathrm{~h}$ after sham operation or CLP in the sarcoplasmic and myofibrillar protein pools, fractionated as described above. Aliquots of the fractions were heated to $100^{\circ} \mathrm{C}$ for $10 \mathrm{~min}$, centrifuged at $800 \mathrm{~g}$ for $10 \mathrm{~min}$ at $4^{\circ} \mathrm{C}$, and the supernatant was assayed for free ubiquitin. Aliquots that were not boiled were assayed for total ubiquitin. The amount of ubiquitin conjugated to protein was calculated as the difference between total and free ubiquitin.

For Western blot analysis, aliquots (10-30 $\mu \mathrm{g}$ ) from the sarcoplasmic and myofibrillar fractions were loaded on an Immobilon polyvinylidenedifluoride (PVDF) transfer membrane (Millipore, Bedford, MA) using a 96-well manifold. The membrane was removed from the manifold and heat fixed at $75^{\circ} \mathrm{C}$ for $30 \mathrm{~min}$. All steps of the immunochemical staining procedure were carried out with constant shaking at room temperature. The membrane was blocked using $25 \mathrm{mg} / \mathrm{ml}$ BSA in buffer A $(25 \mathrm{mM}$ Tris- $\mathrm{HCl}, \mathrm{pH} 7.5,150 \mathrm{mM} \mathrm{NaCl})$ for $2 \mathrm{~h}$. The membranes were incubated for $1.5 \mathrm{~h}$ in buffer A containing BSA and antibody against heat- and SDS-denatured ubiquitin raised in rabbits according to the methods of Rechsteiner (41). Membranes were then washed in buffer A for 10 min followed by two 10-min washes in buffer A plus $0.05 \%$ Triton X-100 and again in buffer $A$ for $10 \mathrm{~min}$. The bound antibody was detected by a 1-h incubation in buffer A containing BSA, $0.05 \%$ Tween 20 , and peroxidase-conjugated IgG. The washes were repeated as above. The membrane was then incubated for $1 \mathrm{~min}$ at room temperature in the presence of Renaissance chemiluminescence reagents (New England Nuclear, Boston, MA). The membrane was blotted dry and exposed to Kodak X-OMAT AR film (Eastman Kodak, Rochester, NY). The spots on the film were quantitated using an Ultrascan XL Enhanced Laser Densitometer (Pharmacia-LKB, Piscataway, NJ) and the results compared with a standard curve generated with free ubiquitin.

Determination of conjugated ubiquitin in fractionated sarcoplasmic and myofibrillar proteins. Aliquots of sarcoplasmic and myofibrillar protein fractions ( $90 \mu \mathrm{g}$ per lane) were electrophoresed (45 $\mathrm{mA}$ ) on a $10 \%$ polyacrylamide gel $(1.5 \times 200 \times 160 \mathrm{~mm})$ in the presence of SDS. After SDS-polyacrylamide gel electrophoresis, the gels were equilibrated in transfer buffer ( $20 \mathrm{mM}$ Tris base, $144 \mathrm{mM}$ glycine, $20 \%$ [ $\mathrm{vol} / \mathrm{vol}]$ methanol) for $30 \mathrm{~min}$. Proteins were then transferred from the slab gel to an Immobilon PVDF transfer membrane by electroelution ( 800 volt hours) using a Trans blot cell (Bio-Rad, Hercules, CA). After heat fixing the membrane at $75^{\circ} \mathrm{C}$ for $30 \mathrm{~min}$, the membrane was blocked 
Table I. Total Protein Breakdown (Tyrosine Release) in Incubated EDL Muscles from Sham-operated Control Rats and from Septic Rats $16 \mathrm{~h}$ after CLP

\begin{tabular}{|c|c|c|c|c|c|c|c|c|c|c|}
\hline \multirow{3}{*}{$\begin{array}{l}\text { Addition to } \\
\text { incubation } \\
\text { medium }\end{array}$} & \multicolumn{5}{|c|}{ Control muscle } & \multicolumn{5}{|c|}{ Septic muscle } \\
\hline & \multicolumn{2}{|c|}{ Tissue level } & \multirow[b]{2}{*}{ Medium } & \multirow[b]{2}{*}{ Net production } & \multirow{2}{*}{$\begin{array}{l}\text { Difference vs. } \\
\text { no addition }\end{array}$} & \multicolumn{2}{|c|}{ Tissue level } & \multirow[b]{2}{*}{ Medium } & \multirow[b]{2}{*}{ Net production } & \multirow{2}{*}{$\begin{array}{c}\text { Difference vs. } \\
\text { no addition }\end{array}$} \\
\hline & $0 \mathrm{~h}$ & $2 \mathrm{~h}$ & & & & $0 \mathrm{~h}$ & $2 \mathrm{~h}$ & & & \\
\hline No addition & $88 \pm 4$ & $101 \pm 12$ & $341 \pm 28$ & $354 \pm 24$ & & $148 \pm 8$ & $186 \pm 11$ & $492 \pm 15$ & $531 \pm 17$ & \\
\hline $\mathrm{NH}_{4} \mathrm{Cl}$ & $56 \pm 3$ & $75 \pm 11$ & $189 \pm 13$ & $209 \pm 21 *$ & 145 & $135 \pm 10$ & $139 \pm 9$ & $333 \pm 7$ & $337 \pm 8 *$ & 194 \\
\hline Chloroquine & $68 \pm 3$ & $102 \pm 6$ & $194 \pm 10$ & $229 \pm 10^{*}$ & 125 & $133 \pm 2$ & $191 \pm 7$ & $330 \pm 8$ & $387 \pm 14^{*}$ & 144 \\
\hline Leupeptin & $68 \pm 4$ & $84 \pm 4$ & $231 \pm 16$ & $262 \pm 14^{*}$ & 92 & $124 \pm 5$ & $143 \pm 6$ & $427 \pm 15$ & $447 \pm 17 *$ & 84 \\
\hline Methylamine & $46 \pm 5$ & $66 \pm 6$ & $200 \pm 17$ & $219 \pm 17 *$ & 135 & $105 \pm 5$ & $138 \pm 14$ & $370 \pm 18$ & $403 \pm 18 *$ & 128 \\
\hline
\end{tabular}

Muscles were incubated in the presence of $10 \mathrm{mM} \mathrm{NH}_{4} \mathrm{Cl}, 250 \mu \mathrm{M}$ chloroquine, $30 \mu \mathrm{M}$ leupeptin, or $10 \mathrm{mM}$ methylamine or with no addition to the incubation medium. The difference in protein breakdown rates between muscles incubated with no addition and muscle incubated with the various additions to the medium reflects lysosomal protein degradation. Results are given as nmol tyrosine/g wet wt for tissue levels and medium and as nmol tyrosine/g wet wt $\times 2 \mathrm{~h}$ for net production and difference vs. no addition. $n=7$ or 8 in each group; $* P<0.05$ vs. no addition.

with BSA ( $25 \mathrm{mg} / \mathrm{ml})$ in buffer A ( $25 \mathrm{mM}$ Tris- $\mathrm{HCl}, \mathrm{pH} 7.5,150 \mathrm{mM}$ $\mathrm{NaCl}$, and $20 \mathrm{mg} / \mathrm{L}$ sodium azide) for $2 \mathrm{~h}$. The membranes were incubated for $1.5 \mathrm{~h}$ in buffer containing BSA and antibody to ubiquitin. Membranes were then washed in buffer A for 10 min followed by two 10 -min washes in buffer A plus $0.05 \%$ ( vol/vol) Triton X-100 and again in buffer $\mathrm{A}$ for $10 \mathrm{~min}$. The bound antibody was detected by a 1 -h incubation in buffer A containing $25 \mathrm{mg} / \mathrm{ml} \mathrm{BSA}$ and ${ }^{125} \mathrm{I}$-protein A $\left(2 \times 10^{5} \mathrm{cpm}\right)$ (Amersham, Arlington Heights, IL). Unbound ${ }^{125} \mathrm{I}-$ protein A was removed by washing with buffer A and buffer A containing Triton $\mathrm{X}-100$ as described above. The membrane was then heat fixed and autoradiographed with Kodak X-OMATAR film with an intensifying screen. The autoradiographs were quantitated using an LKB Ultrascan XL Enhanced Laser Densitometer.

Statistics. Results are presented as means \pm SEM. Student's $t$ test or ANOVA followed by Scheffe's test was used for statistical analysis and $P<0.05$ was considered significant.

\section{Results}

Muscle protein turnover rates and protein content. Protein synthesis rate was reduced by $\sim 25 \%$ (from $211 \pm 4$ to $159 \pm 10$ nmol phenylalanine/g wet wt per $2 \mathrm{~h}$ ) in muscles from septic rats compared with muscles from sham-operated rats $(n=8$ in both groups; $P<0.05$ ). This result is similar to previous reports from our laboratory $(2,4,6,31)$.

Total (tyrosine release) and myofibrillar (3-MH release) protein breakdown rates were increased by $\sim 50$ and $440 \%$, respectively, in muscles from septic rats compared with muscles from sham-operated nonseptic rats (Tables I and II). These results are similar to previous reports from this laboratory in which sepsis in rats resulted in increased protein breakdown in EDL muscle with a particularly pronounced effect on myofibrillar protein breakdown $(1,4,6,31)$. In a previous report (14), the molar ratio of tyrosine/3-MH in isolated myofibrillar protein from rat skeletal muscle was approximately 31:1. This ratio was used to compute the amount of tyrosine released from both myofibrillar and nonmyofibrillar proteins. To calculate the amount of tyrosine released from myofibrillar proteins, the mean values of 3-MH release from muscles incubated without additions in Table II were multiplied by 31 . The tyrosine released from nonmyofibrillar proteins was estimated by subtracting myofibrillar from total tyrosine release (see total tyrosine release from muscles incubated without additions in Table I). Results of these calculations suggest that the increase in muscle protein breakdown during sepsis is primarily due to degradation of myofibrillar proteins (Table III).

$16 \mathrm{~h}$ after CLP or sham operation, muscle weight, and muscle protein content were not significantly different between the two groups of rats (data not shown). Because this may reflect the fact that proteolytic rates were probably not increased during the entire 16-h period after CLP (42), we extended the experi-

Table II. Myofibrillar Protein Breakdown (3-MH Release) in Incubated EDL Muscles from Sham-operated Control Rats and from Septic Rats $16 \mathrm{~h}$ after CLP

\begin{tabular}{|c|c|c|c|c|c|c|c|c|}
\hline \multirow{3}{*}{$\begin{array}{l}\text { Addition to } \\
\text { incubation } \\
\text { medium }\end{array}$} & \multicolumn{4}{|c|}{ Control muscle } & \multicolumn{4}{|c|}{ Septic muscle } \\
\hline & \multicolumn{2}{|c|}{ Tissue level } & \multirow[b]{2}{*}{ Medium } & \multirow[b]{2}{*}{ Net production } & \multicolumn{2}{|c|}{ Tissue level } & \multirow[b]{2}{*}{ Medium } & \multirow[b]{2}{*}{ Net production } \\
\hline & $\mathbf{O h}$ & $2 \mathrm{~h}$ & & & $\mathrm{Oh}$ & $2 \mathrm{~h}$ & & \\
\hline No addition & $4.69 \pm 0.27$ & $3.10 \pm 0.11$ & $2.68 \pm 0.18$ & $1.09 \pm 0.23$ & $7.50 \pm 0.50$ & $5.79 \pm 0.33$ & $7.62 \pm 0.48$ & $5.91 \pm 0.38$ \\
\hline $\mathrm{NH}_{4} \mathrm{Cl}$ & $5.02 \pm 0.31$ & $2.85 \pm 0.30$ & $2.96 \pm 0.15$ & $0.79 \pm 0.23$ & $8.24 \pm 0.63$ & $5.25 \pm 0.61$ & $7.26 \pm 0.39$ & $4.27 \pm 0.52$ \\
\hline Chloroquine & $4.38 \pm 0.40$ & $2.39 \pm 0.34$ & $2.78 \pm 0.15$ & $0.79 \pm 0.78$ & $6.15 \pm 0.51$ & $5.57 \pm 0.49$ & $6.28 \pm 0.48$ & $5.70 \pm 0.49$ \\
\hline Leupeptin & $5.03 \pm 0.41$ & $3.15 \pm 0.29$ & $2.49 \pm 0.05$ & $0.60 \pm 0.22$ & $5.62 \pm 0.24$ & $4.38 \pm 0.20$ & $6.06 \pm 0.23$ & $4.83 \pm 0.27$ \\
\hline Methylamine & $6.33 \pm 0.28$ & $4.10 \pm 0.42$ & $3.55 \pm 0.31$ & $1.31 \pm 0.32$ & $8.78 \pm 0.66$ & $7.70 \pm 0.62$ & $6.72 \pm 0.32$ & $5.64 \pm 0.62$ \\
\hline
\end{tabular}

The concentrations of the different substances in the incubation medium were the same as described in Table I. Results are given as nmol 3-MH/ $\mathrm{g}$ wet $\mathrm{wt}$ for tissue levels and medium and as nmol 3-MH/g wet wt $\times 2 \mathrm{~h}$ for net production. $n=7$ or 8 in each group. 
Table III. Calculated Tyrosine Release from Myofibrillar and Nonmyofibrillar Proteins by Incubated EDL Muscles

\begin{tabular}{lccc}
\hline & \multicolumn{3}{c}{ Tyrosine release } \\
\cline { 2 - 4 } & $\begin{array}{c}\text { Total } \\
\text { protein }\end{array}$ & $\begin{array}{c}\text { Myofibrillar } \\
\text { protein }\end{array}$ & $\begin{array}{c}\text { Nonmyofibrillar } \\
\text { protein }\end{array}$ \\
\hline & & $n m o l / g \times 2 h$ & \\
Control & 354 & 34 & 320 \\
Sepsis & 531 & 183 & 348 \\
& $+50 \%$ & $+438 \%$ & $+9 \%$
\end{tabular}

Tyrosine release from myofibrillar protein was computed by multiplying the mean values of 3-MH release by muscles incubated without addition (Table II) by 31 as described in the text.

mental period $8 \mathrm{~h}$. Results in this experiment showed that muscle weight and sarcoplasmic and myofibrillar protein content were significantly lower in septic than in control rats $24 \mathrm{~h}$ after induction of sepsis (Table IV). The initial muscle weight, calculated from initial body weight as described previously (43), was almost identical in the two groups of rats. The calculated loss of muscle weight during the 24 -h experimental period was more than four times greater in the septic than in the shamoperated rats (Table IV). The results show that the changes in protein synthesis and breakdown rates induced by the present experimental model lead to pronounced muscle catabolism. The finding that both sarcoplasmic and myofibrillar protein content was reduced in septic muscle, despite a predominant increase in myofibrillar proteolysis, suggests that sarcoplasmic protein synthesis rate was inhibited during sepsis.

Lysosomal proteolysis. Total protein breakdown was inhibited both in nonseptic and septic muscle by all lysosomotropic agents tested (Table I). The amount of tyrosine release that could be accounted for by lysosomal proteolysis (i.e., the difference in tyrosine release between muscles incubated in the absence or presence of the different blockers) was similar in control and septic muscle. The difference in net tyrosine release between control and septic muscles was observed even in the presence of the different lysosomal inhibitors. These results suggest that although muscle proteins are hydrolyzed within the lysosome in both control and septic muscle, the lysosomal component of total protein breakdown was not increased in septic muscle.

Myofibrillar protein breakdown was not significantly affected by any of the lysosomotropic agents in control or septic muscle (Table II). These results support the concept that lysosomes are not involved in the degradation of myofibrillar proteins in rat skeletal muscle (14).

$\mathrm{Ca}^{2+}$-dependent proteolysis. Omission of $\mathrm{Ca}^{2+}$ from the incubation medium reduced total protein breakdown by 15 and $22 \%$ in control and septic muscle, respectively (Table V). Muscles from septic rats showed higher protein breakdown rates even in the absence of added $\mathrm{Ca}^{2+}$, suggesting that the sepsisinduced increase in total muscle proteolysis does not reflect an increase in the $\mathrm{Ca}^{2+}$-dependent protein breakdown. When $\mathrm{E}$ 64 was added to muscles incubated in the presence of methylamine, total protein breakdown was not significantly affected in control or septic muscle (Table V), further supporting the concept that increased total muscle protein breakdown during sepsis does not occur via a $\mathrm{Ca}^{2+}$-dependent proteolytic process.
Table IV. Body and Muscle Weight and Muscle Protein Content 24 h after Sham Operation (Control) or CLP (Sepsis)

\begin{tabular}{lcc}
\hline & Control & Sepsis \\
\hline Initial body weight $(\mathrm{g})$ & $60.4 \pm 1.5$ & $60.4 \pm 0.7$ \\
Calculated initial muscle weight $(\mathrm{mg})$ & $57.8 \pm 1.4$ & $57.8 \pm 0.7$ \\
Final muscle weight $(\mathrm{mg})$ & $54.3 \pm 1.4$ & $42.0 \pm 1.4^{*}$ \\
Calculated loss of muscle weight $(\mathrm{mg})$ & $3.6 \pm 0.7$ & $15.8 \pm 1.5^{*}$ \\
Sarcoplasmic protein content $(\mathrm{mg})$ & $2.42 \pm 0.08$ & $2.12 \pm 0.08^{*}$ \\
Myofibrillar protein content (mg) & $1.99 \pm 0.04$ & $1.78 \pm 0.05^{*}$
\end{tabular}

Muscle weights and protein content are from pooled bilateral EDL muscles from individual rats. Initial muscle weight was calculated from initial body weight using the equation $y=-0.660+0.9814 x$, where $x$ $=\ln$ [animal weight] and $y=\ln$ [muscle weight] as described by Fagan and Tischler (43), $n=7$ in each group. ${ }^{*} P<0.05$ vs. control by Student's $t$ test.

Manipulation of $\mathrm{Ca}^{2+}$ concentrations in vitro or addition of E-64 to the incubation medium did not significantly influence $3-\mathrm{MH}$ release in nonseptic or septic muscle (Table VI). These results suggest that the increase in myofibrillar protein breakdown during sepsis is not caused by a $\mathrm{Ca}^{2+}$-dependent mechanism and support a previous report of unchanged myofibrillar protein breakdown rates in rat EDL muscles when intracellular $\mathrm{Ca}^{2+}$ levels were altered (44).

Nonlysosomal, energy-dependent proteolysis. Muscles from sham-operated $(n=7)$ and septic $(n=7)$ rats incubated in the presence of $5 \mathrm{mM} 2-\mathrm{DG}$ and $0.2 \mathrm{mM}$ DNP contained little to no detectable ATP $(0.34 \pm 0.17$ and $0.19 \pm 0.09 \mathrm{nmol} / \mathrm{mg}$ wet wt, respectively) compared with muscles incubated in buffer containing glucose from sham-operated $(6.17 \pm 1.97 \mathrm{nmol} / \mathrm{mg}$ wet wt) and septic $(5.97 \pm 1.14 \mathrm{nmol} / \mathrm{mg}$ wet wt $)$ rats. Total and myofibrillar protein breakdown rates were substantially reduced by energy depletion in both nonseptic and septic muscle ( Table VII ). Calculated as the difference between muscles incubated in the absence or presence of 2-DG and DNP, the energydependent component of total protein breakdown (tyrosine release) was increased in septic muscle by $172 \%$ and that of myofibrillar protein breakdown (3-MH release) was increased more than fourfold. More importantly, total and myofibrillar protein breakdown rates were similar in energy-depleted muscles from septic and control rats. These results suggest that a nonlysosomal energy-dependent proteolytic process may be responsible for the increase in protein breakdown in muscles from septic rats.

Ubiquitin mRNA levels. The structure of the rat ubiquitin gene has not been reported. However, in other species, including man, ubiquitin is encoded in a multigene family. In man, three sizes of mRNA exist, i.e., $2.4,1.2$, and $0.7 \mathrm{~kb}$. They represent different genes encoding for proteins containing varying numbers of ubiquitin molecules connected in series (45).

When ubiquitin mRNA levels in EDL muscles were measured by Northern blot analysis, bands were apparent at 2.4 and $1.2 \mathrm{~kb}$ (Fig. 1). Loading of RNA from control and septic muscle was uniform as demonstrated by similar 18-S bands in the lanes from control and septic muscle. The 2.4-kb message was increased during sepsis whereas the 1.2-kb message did not appear to be changed in septic muscle (Fig. 1). This may reflect differential regulation of family members of the ubiquitin gene during 
Table V. Total Protein Breakdown (Tyrosine Release) in Incubated EDL Muscles from Sham-operated Control Rats and From Septic Rats 16 h after CLP

\begin{tabular}{|c|c|c|c|c|c|c|c|c|}
\hline \multirow{3}{*}{$\begin{array}{l}\text { Addition to incubation } \\
\text { medium }\end{array}$} & \multicolumn{4}{|c|}{ Control muscle } & \multicolumn{4}{|c|}{ Septic muscle } \\
\hline & \multicolumn{2}{|c|}{ Tissue level } & \multirow[b]{2}{*}{ Medium } & \multirow[b]{2}{*}{ Net production } & \multicolumn{2}{|c|}{ Tissue level } & \multirow[b]{2}{*}{ Medium } & \multirow[b]{2}{*}{ Net production } \\
\hline & $0 \mathrm{~h}$ & $2 \mathrm{~h}$ & & & $0 \mathrm{~h}$ & $2 \mathrm{~h}$ & & \\
\hline \multicolumn{9}{|l|}{ Experiment 1} \\
\hline Calcium (2.5 mM) & $67 \pm 3$ & $98 \pm 4$ & $234 \pm 15$ & $265 \pm 12$ & $126 \pm 6$ & $147 \pm 8$ & $433 \pm 26$ & $454 \pm 26$ \\
\hline No calcium & $65 \pm 2$ & $78 \pm 3$ & $211 \pm 6$ & $225 \pm 7 *$ & $127 \pm 4$ & $122 \pm 5$ & $360 \pm 11$ & $355 \pm 11 *$ \\
\hline \multicolumn{9}{|l|}{ Experiment 2} \\
\hline Methylamine & $54 \pm 4$ & $80 \pm 4$ & $214 \pm 15$ & $241 \pm 15$ & $102 \pm 7$ & $126 \pm 10$ & $344 \pm 17$ & $369 \pm 20$ \\
\hline Methylamine + E-64 & $51 \pm 2$ & $68 \pm 4$ & $183 \pm 12$ & $199 \pm 15$ & $104 \pm 4$ & $116 \pm 3$ & $337 \pm 21$ & $349 \pm 19$ \\
\hline
\end{tabular}

In experiment 1 , muscles were incubated in normal medium containing $2.5 \mathrm{mM}$ calcium or in medium with no calcium. In experiment 2 , muscles were incubated in medium with $10 \mathrm{mM}$ methylamine in the absence or presence of $100 \mu \mathrm{M} \mathrm{E}-64$. Results are given as nmol tyrosine/g wet wt for tissue level and medium, and as nmol tyrosine/g wet $\mathrm{wt} \times 2 \mathrm{~h}$ for net production. $n=6$ or 7 in each group; ${ }^{*} P<0.05 \mathrm{vs.} 2.5 \mathrm{mM}$ calcium.

sepsis. Quantitation of Northern blots from three consecutive experiments revealed a 10-, 7-, and 19-fold increase of the 2.4$\mathrm{kb}$ ubiquitin mRNA concentration in muscle from septic rats.

Concentration of free and conjugated ubiquitin. To examine whether the increased concentration of ubiquitin mRNA in muscles from septic rats resulted in an increased amount of ubiquitin protein, muscles were homogenized and fractionated into sarcoplasmic and myofibrillar proteins, and levels of free ubiquitin and ubiquitin bound to proteins were determined. No significant differences in levels of free ubiquitin and total ubiquitin conjugated to myofibrillar and sarcoplasmic proteins were observed between septic and sham-operated rats (Table VIII).

To examine whether muscle proteins of the control and septic rats were differentially ubiquitinated, the myofibrillar and sarcoplasmic proteins were fractionated based on their solubility, run on SDS-polyacrylamide gels, and the ubiquitinated proteins identified by autoradiography of proteins that bound antidenatured ubiquitin antibody and ${ }^{125}$ I-protein A. Proteins from control and septic rats with apparent subunit molecular mass between 18 and $>100 \mathrm{kD}$ in both the sarcoplasmic and myofibrillar fractions were found to be ubiquitinated (Fig. 2, Table IX). In the sarcoplasmic fraction, levels of ubiquitinated proteins with a molecular mass of 36 and $42 \mathrm{kD}$ were decreased in muscles from septic rats by $44(P=0.002)$ and $46 \%(P$ $=0.008$ ), respectively. Although reduced amounts of ubiquitinated proteins with approximate molecular mass of 25 and 18 $\mathrm{kD}$ were observed in the myofibrillar fraction of muscles from septic rats, increased $(P<0.02)$ amounts of higher $(\sim 65$ and $74 \mathrm{kD}$ ) molecular mass ubiquitinated proteins were detected in septic muscles.

\section{Discussion}

The present study tested the role of different proteolytic pathways in sepsis-induced muscle proteolysis. Our results suggest that sepsis stimulates energy-ubiquitin-dependent protein breakdown, whereas no evidence was found for increased activity of lysosomal proteolysis or of the calpains during sepsis. The data are consistent with independent regulation of different intracellular proteolytic pathways in skeletal muscle during sepsis. The results also suggest that increased protein breakdown is not caused by a general increase in protein turnover since protein synthesis rates were reduced in septic muscle.

The present result of inhibited protein breakdown in control and septic muscles incubated in the presence of leupeptin is similar to a previous report from our laboratory (46). In that

Table VI. Myofibrillar Protein Breakdown (3-MH Release) in Incubated EDL Muscles from Sham-operated Control Rats and from Septic Rats $16 \mathrm{~h}$ after CLP

\begin{tabular}{|c|c|c|c|c|c|c|c|c|}
\hline & \multicolumn{4}{|c|}{ Control muscle } & \multicolumn{4}{|c|}{ Septic muscle } \\
\hline & \multicolumn{2}{|c|}{ Tissue level } & \multirow[b]{2}{*}{ Medium } & \multirow[b]{2}{*}{ Net production } & \multicolumn{2}{|c|}{ Tissue level } & \multirow[b]{2}{*}{ Medium } & \multirow[b]{2}{*}{ Net production } \\
\hline & $0 \mathrm{~h}$ & $2 \mathrm{~h}$ & & & $0 \mathrm{~h}$ & $2 \mathrm{~h}$ & & \\
\hline \multicolumn{9}{|l|}{ Experiment 1} \\
\hline Calcium $(2.5 \mathrm{mM})$ & $6.89 \pm 0.19$ & $5.07 \pm 0.29$ & $4.50 \pm 0.36$ & $2.68 \pm 0.44$ & $8.71 \pm 0.54$ & $6.94 \pm 0.45$ & $7.71 \pm 0.61$ & $5.94 \pm 0.58$ \\
\hline No calcium & $6.85 \pm 0.34$ & $4.77 \pm 0.14$ & $4.59 \pm 0.08$ & $2.51 \pm 0.39$ & $8.62 \pm 0.28$ & $6.65 \pm 0.30$ & $7.43 \pm 0.22$ & $5.46 \pm 0.16$ \\
\hline \multicolumn{9}{|l|}{ Experiment 2} \\
\hline Methylamine & $8.09 \pm 0.56$ & $6.04 \pm 0.41$ & $3.93 \pm 0.29$ & $1.88 \pm 0.26$ & $8.65 \pm 0.73$ & $7.16 \pm 0.51$ & $6.50 \pm 0.35$ & $5.00 \pm 0.87$ \\
\hline Methylamine + E-64 & $6.95 \pm 0.40$ & $4.71 \pm 0.37$ & $3.46 \pm 0.25$ & $1.21 \pm 0.26$ & $8.61 \pm 0.53$ & $6.87 \pm 0.64$ & $6.40 \pm 0.45$ & $4.66 \pm 0.46$ \\
\hline
\end{tabular}

The experimental conditions were the same as in Table V. Results are given as nmol 3-MH/g wet wt for tissue level and medium and as nmol $3-\mathrm{MH} / \mathrm{g}$ wet wt $\times 2 \mathrm{~h}$ for net production. $n=6$ or 7 in each group. 
Table VII. Total and Myofibrillar Protein Breakdown Rates in Incubated EDL Muscles from Sham-operated Control Rats and from Septic Rats $16 \mathrm{~h}$ after CLP

\begin{tabular}{|c|c|c|c|c|c|c|c|c|c|c|}
\hline \multirow{3}{*}{$\begin{array}{l}\text { Addition to } \\
\text { incubation }\end{array}$} & \multicolumn{5}{|c|}{ Control muscle } & \multicolumn{5}{|c|}{ Septic muscle } \\
\hline & \multicolumn{2}{|c|}{ Tissue level } & \multirow[b]{2}{*}{ Medium } & \multirow{2}{*}{$\begin{array}{c}\mathrm{Net} \\
\text { production }\end{array}$} & \multirow{2}{*}{$\begin{array}{l}\text { Difference vs. } \\
\text { no addition }\end{array}$} & \multicolumn{2}{|c|}{ Tissue level } & \multirow[b]{2}{*}{ Medium } & \multirow{2}{*}{$\begin{array}{c}\text { Net } \\
\text { production }\end{array}$} & \multirow{2}{*}{$\begin{array}{l}\text { Difference vs } \\
\text { no addition }\end{array}$} \\
\hline & $0 \mathrm{~h}$ & $2 \mathrm{~h}$ & & & & $0 \mathrm{~h}$ & $2 \mathrm{~h}$ & & & \\
\hline \multicolumn{11}{|l|}{ Tyrosine release } \\
\hline- & $46 \pm 7$ & $84 \pm 7$ & $225 \pm 10$ & $262 \pm 14$ & & $133 \pm 7$ & $170 \pm 11$ & $419 \pm 14$ & $456 \pm 15$ & \\
\hline 2-DG + DNP & $81 \pm 5$ & $119 \pm 6$ & $122 \pm 12$ & $158 \pm 11^{*}$ & 104 & $107 \pm 7$ & $140 \pm 14$ & $149 \pm 6$ & $182 \pm 11^{*}$ & 274 \\
\hline \multicolumn{11}{|l|}{ 3-MH release } \\
\hline- & $6.28 \pm 0.30$ & $4.07 \pm 0.42$ & $3.16 \pm 0.13$ & $1.58 \pm 0.41$ & & $8.24 \pm 0.55$ & $7.60 \pm 0.49$ & $6.18 \pm 0.49$ & $5.53 \pm 0.70$ & \\
\hline $2-\mathrm{DG}+\mathrm{DNP}$ & $6.26 \pm 0.52$ & $4.02 \pm 0.22$ & $2.73 \pm 0.24$ & $0.49 \pm 0.53 *$ & 1.09 & $5.82 \pm 0.61$ & $3.60 \pm 0.70$ & $3.17 \pm 0.28$ & $0.95 \pm 0.31 *$ & 4.58 \\
\hline
\end{tabular}

Muscles were incubated in medium containing $5 \mathrm{mM}$ glucose or in medium without glucose but containing $5 \mathrm{mM}$ 2-DG and 0.2 mM DNP. The difference in protein breakdown rate between muscles incubated under the different conditions reflects the energy-dependent component of protein breakdown. Results are given as nmol tyrosine or $3-\mathrm{MH} / \mathrm{g}$ wet wt for tissue levels and medium and as nmol tyrosine or $3-\mathrm{MH} / \mathrm{g}$ wet $\mathrm{wt} \times 2 \mathrm{~h}$ for net production and difference vs. no addition. $n=6$ or 7 in each group. $* P<0.05$ vs. no addition to incubation medium.

study as well, protein breakdown in septic muscle was not reduced to control values by leupeptin. In another study (47), we treated septic rats in vivo with leupeptin and, again, total protein breakdown in EDL muscle was reduced, but not to normal levels. Because cathepsin B activity was increased in septic EDL muscle (46), the data in our previous reports were interpreted as indicating that lysosomal protein breakdown contributes to, but is not the only mechanism of, increased muscle proteolysis during sepsis. The present study extended our previous reports by comparing the effects of different lysosomotropic agents and by determining the effects of these substances on myofibrillar protein degradation. The results suggest that the role of lysosomal protein breakdown in the increased muscle proteolysis during sepsis is small, if any.

The finding in this study of unaffected myofibrillar protein breakdown when muscles were incubated in the presence of the different lysosomotropic agents supports a previous report by Lowell et al. (14) in which evidence was found that lysosomes are not involved in the degradation of myofibrillar proteins in rat skeletal muscle. This further supports the concept that lysosomal proteolysis is not the major mechanism of sepsisinduced muscle proteolysis, since myofibrillar proteins are particularly sensitive to the effects of sepsis (1).

Previous reports of increased protein breakdown after the addition of $\mathrm{Ca}^{2+}$ or the calcium ionophore A 23187 to incubated muscles in vitro are consistent with the presence of $\mathrm{Ca}^{2+}$-dependent proteolytic pathway $(\mathrm{s})(48,49)$. There is evidence that

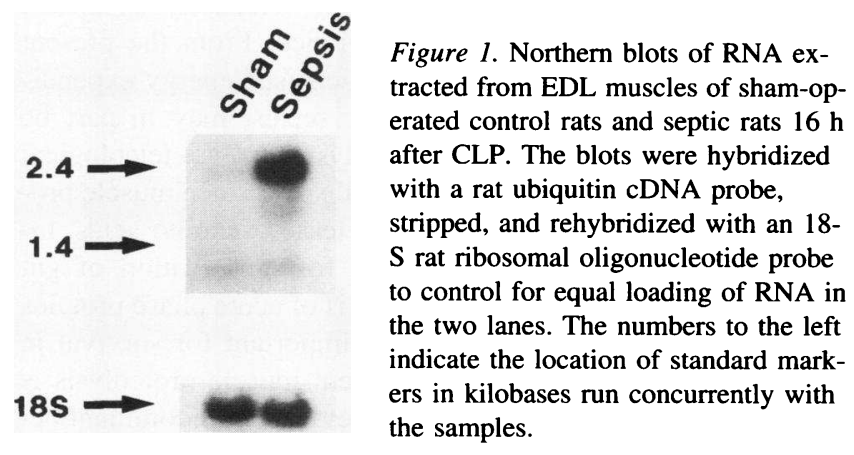

most of the $\mathrm{Ca}^{2+}$-dependent proteolysis is nonlysosomal (9). Muscle contains at least two soluble $\mathrm{Ca}^{2+}$-requiring proteases, calpain I and II $(23,24)$, and these enzymes may be responsible for the nonlysosomal $\mathrm{Ca}^{2+}$-dependent proteolytic activity. It should be noted that most studies of $\mathrm{Ca}^{2+}$-activated proteolysis have been performed in vitro and the role of $\mathrm{Ca}^{2+}$ for regulation of muscle proteolysis in vivo is unclear.

The results in the present study suggest that $\mathrm{Ca}^{2+}$-dependent protein breakdown does not play a major role in sepsis-induced muscle proteolysis. This finding supports a previous report from our laboratory in which the $\mathrm{Ca}^{2+}$ channel blocker verapamil reduced total protein breakdown in control muscle incubated in the presence of $2.5 \mathrm{mM} \mathrm{Ca}^{2+}$ but did not influence total or myofibrillar protein degradation in septic muscle (50). Although uptake of $\mathrm{Ca}^{2+}$ and $\mathrm{Ca}^{2+}$ content were increased in muscle from septic rats in that study (50), the increase in $\mathrm{Ca}^{2+}$ content was more pronounced in soleus than in EDL muscle, in contrast to protein breakdown, which was more stimulated in EDL than in soleus (1). Furthermore, $\mathrm{Ca}^{2+}$ in the medium stimulated total, but not myofibrillar, protein degradation in incubated muscle (50), which differs from the pronounced ef-

Table VIII. Concentrations of Free and Conjugated Ubiquitin in EDL Muscles $16 \mathrm{~h}$ after Sham Operation (Control) or CLP (Sepsis) in Rats

\begin{tabular}{lcc}
\hline & Control & Sepsis \\
\hline $\begin{array}{l}\text { Free ubiquitin } \\
\text { Ubiquitin conjugated to } \\
\text { myofibrillar proteins } \\
\begin{array}{c}\text { Ubiquitin conjugated to } \\
\text { sarcoplasmic proteins }\end{array}\end{array}$ & $8.47 \pm 0.30$ & $8.55 \pm 0.43$ \\
\hline
\end{tabular}

Sarcoplasmic and myofibrillar proteins were fractionated by differential centrifugation of homogenates prepared from individual EDL muscles from control and septic rats ( $n=7$ per group). Samples (10-30 $\mu \mathrm{g})$ were dot blotted onto a PVDF membrane, probed with antibody to ubiquitin, and bound antibody was detected using a chemiluminescent assay as described in Methods. Results are given as $\mu \mathrm{g}$ ubiquitin $/ \mathrm{mg}$ protein. 


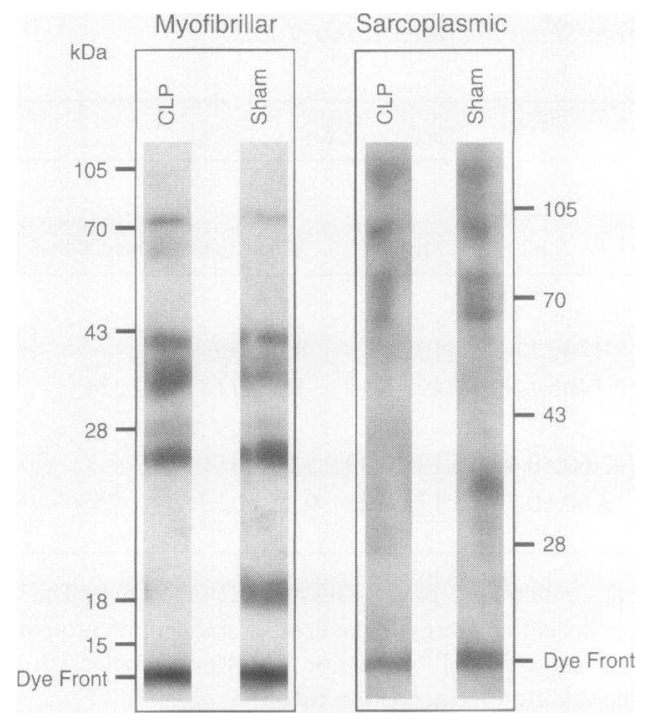

Figure 2. Conjugation of ubiquitin to myofibrillar and sarcoplasmic proteins in EDL muscles from sham-operated control rats and from septic rats $16 \mathrm{~h}$ after CLP. Aliquots $(90 \mu \mathrm{g})$ of either sarcoplasmic or myofibrillar protein were loaded per lane on $10 \%$ SDS-polyacrylamide gels. Proteins were transferred to PVDF Immobilon membranes. The ubiquitinated proteins were detected using anti-denatured ubiquitin antibody and ${ }^{125} \mathrm{I}$-protein $\mathrm{A}$ and visualized by autoradiography.

fect of sepsis on myofibrillar protein breakdown (1). These observations, together with the results in the present report, make it unlikely that increased muscle proteolysis during sepsis reflects stimulated $\mathrm{Ca}^{2+}$-dependent protein breakdown. It should be noted that a different conclusion was made in a recent study, in which increased $\mathrm{Ca}^{2+}$-dependent cytosolic protease activity was reported in posterior leg muscles from septic rats (51). Interpretation of results in that study, however, is complicated by the fact that no measurements of protein breakdown rates were performed. Also it is not known in which type of muscle enzyme activity was measured since posterior leg muscles contain both red slow-twitch and white fast-twitch muscles. As pointed out above, the metabolic response to sepsis is different in different types of skeletal muscle, with the influence of sepsis on total and myofibrillar protein breakdown being more pronounced in the white fast-twitch EDL muscle than in the red slow-twitch soleus muscle (1). In recent experiments, we found evidence that sepsis-induced increases in energy-dependent proteolysis and ubiquitin mRNA levels are specific for white fast-twitch muscle with no changes noticed in red slowtwitch muscle (unpublished observations). Thus, studies in individual muscles are preferable when sepsis-induced metabolic changes are examined.

It is an old observation that energy is required for protein degradation. Simpson (52) reported 40 years ago that the release of amino acids from radiolabeled proteins in incubated liver slices was reduced when the supply of ATP was limited. A number of subsequent studies have provided evidence for energy-dependent proteolysis both in prokaryotic and eukaryotic cells (for review see reference 53). The most extensively studied nonlysosomal proteolytic mechanism is the ATP-ubiquitin-dependent proteolytic pathway (15). This pathway was thought to be primarily responsible for degrading abnormal proteins and short-lived regulatory proteins (53). Recent studies
Table IX. Ubiquitination of Myofibrillar and Sarcoplasmic Proteins in Muscles from Control and Septic Rats

\begin{tabular}{cccc}
\hline $\begin{array}{c}\text { Approximate molecular } \\
\text { weight }\end{array}$ & Control & Sepsis & $P$ value \\
\hline \multicolumn{1}{c}{$k D$} & & & \\
Myofibrillar & & & \\
74 & $26.2 \pm 7.5$ & $53.2 \pm 6.5$ & 0.0184 \\
65 & $0.0 \pm 0.0$ & $31.9 \pm 6.5$ & 0.0001 \\
42 & $92.7 \pm 7.5$ & $103.7 \pm 9.9$ & 0.3931 \\
$36+39$ & $127.7 \pm 18.2$ & $168.5 \pm 20.9$ & 0.1665 \\
30 & $16.7 \pm 5.2$ & $28.9 \pm 4.5$ & 0.0965 \\
25 & $197.4 \pm 12.6$ & $148.6 \pm 21.1$ & 0.0699 \\
18 & $202.2 \pm 5.5$ & $20.1 \pm 9.7$ & 0.0001 \\
& & & \\
Total & $677.7 \pm 56.7$ & $586.2 \pm 35.5$ & 0.1964 \\
Sarcoplasmic & & & \\
$>100$ & $112.6 \pm 4.8$ & $107.5 \pm 8.8$ & $>0.5$ \\
92 & $116.0 \pm 22.2$ & $105.6 \pm 23.6$ & $>0.5$ \\
82 & $79.8 \pm 16.5$ & $56.5 \pm 5.1$ & 0.2030 \\
65 & $80.2 \pm 21.9$ & $76.2 \pm 17.0$ & $>0.5$ \\
42 & $25.5 \pm 2.9$ & $13.7 \pm 5.6$ & 0.0088 \\
39 & $51.8 \pm 5.3$ & $65.5 \pm 6.5$ & 0.1294 \\
36 & $51.9 \pm 5.5$ & $28.9 \pm 2.5$ & 0.0024 \\
Total & $542.6 \pm 40.2$ & $457.5 \pm 29.9$ & 0.1150 \\
& & & \\
\hline & & &
\end{tabular}

Proteins were fractionated from individual EDL muscles $(n=7$ per group) and aliquots (90 $\mu \mathrm{g}$ per lane) were electrophoresed on a $10 \%$ polyacrylamide gel in the presence of SDS. Proteins were transferred from the slab gel onto a PVDF membrane and incubated in buffer containing ubiquitin antiserum. Bound antibody was detected using ${ }^{125} \mathrm{I}$ protein A and quantitated by densitometry as described in Methods. Results are given as ng ubiquitin/90 $\mu \mathrm{g}$ protein.

suggest, however, that this system is also involved in the breakdown of myofibrillar proteins in skeletal muscle during certain catabolic conditions, such as denervation, starvation, metabolic acidosis, and cancer (16-20). In addition to the ubiquitin system, there is evidence that muscle and other mammalian cells contain a nonlysosomal ATP-dependent pathway that does not require ubiquitin (21), but the biological role of this pathway is not known at present.

The results in the current study suggest that most of the sepsis-induced increase in muscle protein breakdown reflects nonlysosomal energy-dependent proteolysis. Energy requirement for proteolysis may seem surprising from a thermodynamic standpoint since hydrolysis of peptide bonds is usually a spontaneous exergonic process. It is possible that the energy dependency reflects the high degree of selectivity by which specific intracellular proteins are degraded. From the present results it may be speculated that the increased energy expenditure, characteristic of hypermetabolic sepsis, may in part be explained by increased muscle proteolysis. From a teleological standpoint, this energy is probably well spent since muscle protein breakdown results in increased release of amino acids, including glutamine, that can be used for preservation of gut mucosal integrity $(54,55)$ and synthesis of acute phase proteins in the liver (56), both of which are important for survival in sepsis. The finding of energy-dependent muscle proteolysis is important because it contradicts the previously predominant be- 
lief that proteolysis during sepsis is caused by energy deficit in muscle tissue (57).

Increased ubiquitin mRNA levels in muscle from septic rats, as observed here, suggest that the energy-dependent component of muscle proteolysis during sepsis may represent ubiquitindependent protein breakdown and that this proteolytic pathway may be activated at the transcriptional level. Unchanged concentrations of free and total conjugated ubiquitin in muscle from septic rats, despite increased mRNA levels, were surprising but do not necessarily argue against a role of ubiquitin-dependent proteolysis during sepsis. It is possible, for example, that both synthesis (as indicated by increased mRNA levels) and breakdown of ubiquitin are upregulated during sepsis, consistent with an increased turnover of ubiquitin and stimulated activity in the ubiquitin-dependent proteolytic pathway. Results from the experiments in which ubiquitination of different fractions of sarcoplasmic and myofibrillar proteins was measured suggest that determination of the total amount of conjugated ubiquitin, as done in previous studies $(16,20)$, does not adequately reflect ubiquitination of individual proteins. More work will be needed in the future to better define the role of the ubiquitin system in sepsis-induced muscle proteolysis. In addition to determining which specific proteins that are ubiquitinated at an increased rate during sepsis, it will be important to determine the activity of the major proteolytic enzyme in the ubiquitin pathway, i.e., the $1,500-\mathrm{kD}(26 \mathrm{~S})$ proteolytic complex $(15,58)$. Furthermore, it will be important to determine if increased ubiquitin mRNA levels reflect stimulated transcription of the ubiquitin gene and/or increased stability of the messenger. A close correlation between ubiquitin mRNA levels and energy-dependent muscle proteolysis, as noted in the present report, has been observed in other conditions characterized by muscle atrophy, including fasting, denervation, and metabolic acidosis (16-19). Parallel changes in ubiquitin mRNA levels and energy-dependent proteolysis have also been noted after hormonal treatment (17). Thus, it is reasonable to assume that these changes are linked and that increased energy-dependent protein breakdown in these conditions reflects stimulation of the ubiquitin system.

\section{Acknowledgments}

This study was supported in part by National Institutes of Health (NIH) grants DK-37908, HD-20748 and AR-38867, by grant 15861 from the Shriners of North America, and by U. S. Department of Agriculture grant 90-37265-5454. G. Tiao was also supported by NIH Training Program 1 T32 GM08478.

\section{References}

1. Hasselgren, P. O., J. H. James, D. W. Benson, M. Hall-Angerås, D. T., Hiyama, S. Li, and J. E. Fischer. 1989. Total and myofibrillar protein breakdown in different types of rat skeletal muscle: effects of sepsis and regulation by insulin. Metab. Clin. Exp. 38:634-640.

2. Hummel, R. P., P. O. Hasselgren, J. H. James, B. W. Warner, and J. E. Fischer. 1988. The effect of sepsis in rats on skeletal muscle protein synthesis in vivo and in periphery and central core of incubated muscle preparations in vitro. Metab. Clin. Exp. 37:1120-1127.

3. Hasselgren, P. O., J. H. James, and J. E. Fischer. 1986. Inhibited muscle amino acid uptake in sepsis. Ann. Surg. 203:360-365.

4. Hall-Angerås, M., U. Angerås, O. Zamir, P. O. Hasselgren, and J. E. Fischer. 1991. Effect of the glucocorticoid receptor antagonist RU 38486 on muscle protein breakdown in sepsis. Surgery (St. Louis). 109:468-473.

5. Zamir, O., P. O. Hasselgren, T. Higashiguchi, J. A. Frederick, and J. E. Fischer. 1992. Tumor necrosis factor (TNF) and interleukin-1 (IL-1) induce muscle proteolysis through different mechanisms. Mediat. Inflam. 1:247-250.

6. Zamir, O., P. O. Hasselgren, S. L. Kunkel, J. A. Frederick, T. Higashiguchi, and J. E. Fischer. 1992. Evidence that tumor necrosis factor participates in the regulation of muscle proteolysis during sepsis. Arch. Surg. 127:170-179.

7. Zamir, O., P. O. Hasselgren, W. O'Brien, R. C. Thompson, and J. E. Fischer. 1992. Muscle protein breakdown during endotoxemia in rats and after treatment with interleukin-1 receptor antagonist (IL-1ra). Ann. Surg. 216:381387

8. Glaumann, H., and F. J. Ballard, editors. 1987. Lysosomes. Their Role in Protein Breakdown. Academic Press, Orlando, FL.

9. Furuno, K., and A. L. Goldberg. 1986. The activation of protein degradation in muscle by calcium or muscle injury does not involve a lysosomal mechanism. Biochem. J. 237:859-864.

10. Fulks, R., J. B. Li, and A. L. Goldberg. 1975. Effects of insulin, glucose, and amino acids on protein turnover in rat diaphragm. J. Biol. Chem. 250:290298 .

11. Long, W. M., B. H. Chua, N. Laulensach, and H. E. Morgan. 1983. Effects of amino acid methylesters on cardiac lysosomes and protein degradation. Am. J. Physiol. 245:C101-C112.

12. Garlick, P. J., V. R. Preedy, and P. J. Reeds. 1985. Regulation of protein turnover in vivo by insulin and amino acids. In Intracellular Protein Catabolism. E. A. Khairallah, J. S. Bond, and J. S. W. Bird, editors. Alan R. Liss, Inc., New York. 555-564.

13. Bird, J. W., J. H. Carter, R. E. Triemer, R. M. Brooks, and A. M. Spanier. 1980. Proteinases in cardiac and skeletal muscle. Fed. Proc. 39:20-25.

14. Lowell, B. B., N. B. Ruderman, and M. N. Goodman. 1986. Evidence that lysosomes are not involved in the degradation of myofibrillar proteins in rat skeletal muscle. Biochem. J. 234:237-240.

15. Hershko, A., and A. Ciechanover. 1992. The ubiquitin system for protein degradation. Annu. Rev. Biochem. 61:761-807.

16. Medina, R., S. S. Wing, A. Haas, and A. L. Goldberg. 1991. Activation of the ubiquitin-ATP-dependent proteolytic system in skeletal muscle during fasting and denervation atrophy. Biomed. Biochim. Acta. 50:347-356.

17. Wing, S., and A. L. Goldberg. 1993. Glucocorticoids activate the ATPubiquitin-dependent proteolytic system in skeletal muscle during fasting. Am. J. Physiol. 264:E668-E676.

18. Furuno, K., M. N. Goodman, and A. L. Goldberg. 1990. Role of different proteolytic systems in the degradation of muscle proteins during denervation atrophy. J. Biol. Chem. 265:8550-8557.

19. Mitch, W. E., R. Medina, S. Grieber, R. C. May, B. K. England, S. R. Price, J. L. Bailey, and A. L. Goldberg. 1994. Metabolic acidosis stimulates muscle protein degradation by activating the adenosine triphosphate-dependent pathway involving ubiquitin and proteasomes. J. Clin. Invest. 93:2127-2133.

20. Llovera, M., C. Garcia-Martinez, N. Agell, M. Marzabal, F. J. LopezSoriano, and J. M. Argiles. 1994. Ubiquitin gene expression is increased in skeletal muscle of tumour-bearing rats. FEBS (Fed. Eur. Biochem. Soc.) Lett. 338:311318

21. Fagan, J. M., and L. Waxman. 1989. A novel ATP-requiring protease from skeletal muscle that hydrolyzes non-ubiquitinated proteins. J. Biol. Chem. 264:17868-17872.

22. Fagan, J. M., E. F. Wajnberg, L. A. Culbert, and L. Waxman. 1992. ATP depletion stimulates calcium-dependent protein breakdown in chick skeletal muscle. Am. J. Physiol. 262:E637-E643.

23. Waxman, L. 1981. Calcium-activated proteases in mammalian tissues. Methods Enzymol. 80:664-680.

24. Mellgren, R. 1987. Calcium-dependent proteases: an enzyme system active at cellular $\gamma$-membranes. FASEB (Fed. Am. Soc. Exp. Biol.) J. 1:110-115.

25. Houssain, H., G. A. Dudley, and P. Johnson. 1987. Effects of denervation on calpain and calpastatin in hamster skeletal muscles. Exp. Neurol. 97:635-643.

26. Johnson, P., and J. L. Hammer. 1988. Calpain and calpastatin levels in dystrophic hamster skeletal muscle. Int. J. Biochem. 20:1227-1230.

27. Gecha, O. M., and J. M. Fagan. 1992. Protective effect of ascorbic acid on the breakdown of proteins exposed to $\mathrm{H}_{2} \mathrm{O}_{2}$ in muscle. J. Nutr. 122:20872093.

28. Fagan, J. M., and L. Waxman. 1992. Characterization of the ATP-independent pathway in red blood cells that degrades oxidant-damaged hemoglobin. $J$. Biol. Chem. 267:23015-23022.

29. Pedersen, P. V., B. W. Warner, H. S. Bjornson, D. T. Hiyama, S. Li, D. F. Rigel, P. O. Hasselgren, and J. E. Fischer. 1989. Hemodynamic and metabolic alterations during experimental sepsis in young and adult rats. Surg. Gynecol. Obstet. 168:148-156.

30. Chaudry, I. H., K. A. Wichterman, and A. E. Baue. 1979. Effect of sepsis on tissue adenine nucleotide levels. Surgery (St. Louis). 85:205-211.

31. Hall-Angerås, M., U. Angerås, D. von Allmen, T. Higashiguchi, O. Zamir, P. O. Hasselgren, and J. E. Fischer. 1991. Influence of sepsis in rats on muscle protein turnover in vivo and in tissue incubated under different in vitro conditions. Metab. Clin. Exp. 40:247-251.

32. Hasselgren, P. O., M. Hall-Angerås, U. Angerås, D. Benson, J. H. James, and J. E. Fischer. 1990. Regulation of total and myofibrillar protein breakdown in rat extensor digitorum longus and soleus muscle incubated flaccid or at resting length. Biochem. J. 267:37-44.

33. Baracos, V. E., and A. L. Goldberg. 1986. Maintenance of normal length 
improves protein balance and energy status in isolated rat skeletal muscle. Am. J. Physiol. 251:C588-C596.

34. Young, V. R., and H. N. Munro. 1978. $\mathrm{N}^{\tau}$-methylhistidine (3-methylhistidine) and muscle protein turnover: an overview. Fed. Proc. 37:2291-2300.

35. Barrett, A. J., A. A. Kembhari, M. A. Brown, H. Kirchke, G. G. Knight, M Tamai, and K. Hanada. 1982. L-Trans-epoxysuccinyl-leucylamido (4-guanido) butane (E-64) and its analogues as inhibitors of cysteine proteinases including cathepsins B, H, and L. Biochem. J. 201:189-197.

36. Mallette, L., J. Exton, and C. Park. 1969. Control of gluconeogenesis from amino acids in the perfused rat liver. J. Biol. Chem. 244:5713-5723.

37. Deluca, M., and W. D. McElroy. 1978. Purification and properties of firefly luciferase. Methods Enzymol. 57:3-15.

38. Etlinger, J. D., R. Zak, and D. A. Fischman. 1976. Compositional studies of myofibrils from rabbit striated muscle. J. Cell Biol. 68:123-141.

39. Lowry, O. H., N. J. Rosebrough, A. L. Farr, and R. J. Randall. 1951. Protein measurement with the Folin phenol reagent. J. Biol. Chem. 193:265-275.

40. Sambrook, J., E. Fritsch, and T. Maniatis. 1989. Molecular Cloning. 2nd ed. Cold Spring Harbor Press, Cold Spring Harbor, NY.

41. Rechsteiner, M. 1988. Ubiquitin. Plenum Press, New York.

42. Hasselgren, P. O., M. Talamini, J. H. James, and J. E. Fischer. 1986 Protein metabolism in different types of skeletal muscle during early and late sepsis in rats. Arch. Surg. 121:918-923.

43. Fagan, J. M., and M. E. Tischler. 1986. Reduction-oxidation state and protein degradation in skeletal muscles of growing rats. Growth 50:139-146.

44. Goodman, M. N. 1987. Differential effects of acute changes in cell $\mathrm{Ca}^{2+}$ concentration on myofibrillar and non-myofibrillar protein breakdown in the rat extensor digitorum longus muscle in vitro. Biochem. J. 241:121-127.

45. Wiborg, O., M. S. Pedersen, A. Wind, L. E. Berglund, K. A. Marcker, and J. Vuust. 1985. The human ubiquitin multigene family: some genes contain multiple directly repeated ubiquitin coding sequences. EMBO (Eur. Mol. Biol. Organ.) J. 4:755-759.

46. Hummel, R. P., J. H. James, B. W. Warner, P. O. Hasselgren, and J. E. Fischer. 1988. Evidence that cathepsin B contributes to skeletal muscle protein breakdown during sepsis. Arch. Surg. 123:221-224.
47. Hummel, R. P., B. W. Warner, J. H. James, P. O. Hasselgren, and J. E. Fischer. 1988. Effects of indomethacin and leupeptin on muscle cathepsin B activity and protein degradation during sepsis. J. Surg. Res. 45:140-144.

48. Sugden, P. H. 1980. The effects of calcium ions, ionophore A23187 and inhibition of energy metabolism on protein degradation in rat diaphragm and epitrochlearis muscles in vitro. Biochem. J. 190:593-603.

49. Lewis, S. E., P. Anderson, and D. F. Goldspink. 1982. The effects of calcium on protein turnover in skeletal muscles of the rat. Biochem. J. 204:257264.

50. Benson, D. W., P. O. Hasselgren, D. T. Hiyama, J. H. James, S. Li D. F. Rigel, and J. E. Fischer. 1989. Effect of sepsis on calcium uptake and content in skeletal muscle and regulation in vitro by calcium of total and myofibrillar protein breakdown in control and septic muscle: results from a preliminary study. Surgery (St. Louis). 106:87-93.

51. Bhattacharyya, J., K. Thompson, and M. M. Sayeed. 1991. Calciumdependent and calcium-independent protease activities in skeletal muscle during sepsis. Circ. Shock. 35:117-122.

52. Simpson, M. V. 1953. The release of labelled amino acids from the proteins of rat liver slices. J. Biol. Chem. 201:143-154.

53. Goldberg, A. L. 1992. The mechanisms and functions of ATP-dependent proteases in bacterial and animal cells. Eur. J. Biochem. 203:9-23.

54. Souba, W. W., R. J. Smith, and D. W. Wilmore. 1985. Glutamine metabolism by the intestinal tract. J. Parenter. Enteral Nutr. 9:608-617.

55. Wilmore, D. W., R. J. Smith, T. Sarah, S. T. O'Dwyer, D. O. Jacobs, T. R. Ziegler, and X. D. Wang. 1988. The gut: a central organ after surgical stress. Surgery (St. Louis). 104:917-923.

56. Sax, H. C., M. A. Talamini, P. O. Hasselgren, L. Rosenblum, C. K. Ogle, and J. E. Fischer. 1988. Increased synthesis of secreted hepatic proteins during abdominal sepsis. J. Surg. Res. 44:109-116.

57. Clowes, G. H. A., T. F. O'Donnell, G. L. Blackburn, and T. N. Maki 1976. Energy metabolism and proteolysis in traumatized and septic man. Surg. Clin. North Am. 56:1169-1184.

58. Fagan, J. M., L. Waxman, and A. L. Goldberg. 1987. Skeletal muscles and liver contain a soluble ATP + ubiquitin-dependent proteolytic system. Biochem. J. 243:335-343. 